\title{
PERSISTENCE OF ATRAZINE, METRIBUZIN AND SIMAZINE HERBICIDES IN TWO SOILS1
}

\author{
FEDERICO FUSCALDO ${ }^{2}$, FRANCISCO BEDMAR ${ }^{3}$ and GLORIA MONTERUBBIANESI ${ }^{4}$
}

\begin{abstract}
An oat bioassay was conducted in pots under greenhouse conditions to determine the persistence of atrazine, metribuzin and simazine herbicides in soils of the southeast of Buenos Aires Province, Argentina. Atrazine rates of $0,0.58,1.16$ and $2.32 \mu \mathrm{g} \mathrm{g}^{-1}$ of active ingredient (a.i.), metribuzin rates of $0,0.14,0.28$ and $0.56 \mu \mathrm{g} \mathrm{g} \mathrm{g}^{-1}$ of a.i., and simazine rates of $0,0.72,1.45$ and $2.9 \mu \mathrm{g} \mathrm{g} \mathrm{g}^{-1}$ of a.i. dry soil weight were applied to pots containing soils from Balcarce and San Cayetano sites. Organic matter $(\mathrm{OM})$ content and $\mathrm{pH}$ of Balcarce soil were $5.5 \%$ and $5.8 \%$, while for San Cayetano soil were $2.9 \%$ and $6.7 \%$, respectively. Relative dry weight (RDW) of oat shoots was calculated as percentage of control. Considering a $20 \%$ RDW reduction of oat shoots, persistences of recommended rates for the region were: atrazine (1.16 $\mu \mathrm{g} \mathrm{g}^{-1}$ of a.i.), 78 and 130 days after treatment (DAT) for Balcarce and San Cayetano soil, respectively; metribuzin $\left(0.28 \mu \mathrm{g}^{-1}\right.$ of a.i.), 63 and 77 DAT for Balcarce and San Cayetano soil, respectively; simazine (1.45 $\mu \mathrm{g} \mathrm{g}^{-1}$ of a.i.), 81 and 156 DAT for Balcarce and San Cayetano soil, respectively. Results show that persistence of atrazine, metribuzin and simazine in soil increased with high rates, low $\mathrm{OM}$ content and high $\mathrm{pH}$.
\end{abstract}

Index terms: oat, organic matter, $\mathrm{pH}$, herbicide rates, bioassay.

PERSISTÊNCIA DOS HERBICIDAS ATRAZINE, METRIBUZIN E SIMAZINE EM DOIS SOLOS

RESUMO - O presente trabalho foi realizado para estudar a persistência dos herbicidas atrazine, metribuzin e simazine em solos do sudeste da Província de Buenos Aires, Argentina, por meio de um bioensaio com aveia. Doses de atrazine de $0,0,58,1,16$ e 2,32 $\mu \mathrm{g} \mathrm{g}^{-1}$ de ingrediente ativo (i.a.), doses de metribuzin de $0,0,14,0,28$ e $0,56 \mu \mathrm{g} \mathrm{g}^{-1}$ de i.a., e doses de simazine de $0,0,72,1,45$ e $^{2,9} \mu \mathrm{g} \mathrm{g}^{-1} \mathrm{de}^{\text {i.a. }}$ de solo seco, foram aplicadas em vasos que continham solos de Balcarce e San Cayetano. O conteúdo de matéria orgânica (MO) e o pH do solo de Balcarce foram 5,5\% e 5,8\%, enquanto no solo de San Cayetano foram $2,9 \%$ e $6,7 \%$, respectivamente. Com a parte aérea das plantas de aveia calculou-se o peso relativo da matéria seca (PSR) em relação ao tratamento sem herbicida. Considerando uma redução de $20 \%$ do PSR, as persistências nas doses recomendadas para os solos de Balcarce e San Cayetano foram, respectivamente: atrazine (1,16 $\mathrm{g} \mathrm{g} \mathrm{g}^{-1}$ de i.a.), $78 \mathrm{e} 130$ dias após tratamento (DAT); metribuzin $\left(0,28 \mu \mathrm{g} \mathrm{g}^{-1}\right.$ de i.a. $), 63$ e 77 DAT; simazine ( $1,45 \mu \mathrm{g} \mathrm{g} \mathrm{g}^{-1}$ de i.a. $), 81$ e 156 DAT. Os resultados indicam que a persistência foi maior com altas doses dos herbicidas, com baixo conteúdo de $\mathrm{MO}$ e alto $\mathrm{pH}$ dos solos.

Termos para indexação: aveia, matéria orgânica, $\mathrm{pH}$, doses de herbicidas, bioensaio.

\footnotetext{
${ }^{1}$ Accepted for publication on November 25, 1998. Supported by Facultad de Ciencias Agrarias (FCA), Universidad Nacional de Mar del Plata (UNMDP) and Instituto Nacional de Tecnología Agropecuaria (INTA).

2 Agronomist, Dep. de Producción Vegetal, FCA-UNMDP, C.C. 276, 7620 Balcarce, Argentina.

3 Agronomist, M.Sc., Prof. Adj., Dep. de Producción Vegetal, FCA-UNMDP. E-mail: fbedmar@inta.gov.ar

${ }^{4}$ Mathematician, Dep. de Estadística y Diseño, FCA-UNMDP.
}

\section{INTRODUCTION}

The persistence of a pesticide in the soil is defined as the period or extension of time in which it remains active. Knowing the case of herbicides is particularly important because, on one hand, it determines the period of time in which weeds can be controlled, and on the other, it is related to the later 
phytotoxic effects which can damage the subsequent crops. The persistence has also got influence in the risk of its moving towards the groundwater causing its contamination. The persistence of a herbicide in the soil is the result of the interaction of edaphic and climatic factors and of the very same herbicide. Between the former, the adsorption to the organic and inorganic colloids is one of the most influential ones according to the availability of the herbicide in the soil, existing a better correlationship between the organic matter (OM) content and the adsorption than the one that exists with clays (Sheets et al., 1962; Talbert \& Fletchall, 1965; Horowitz, 1969). Triazine herbicides (atrazine and simazine) and triazinones (metribuzin) are found among the pesticides most widely used worldwide (Sattin et al., 1995). Moreover, in the case of atrazine, due to its high frequency in use and its mobility in the soil, its presence in groundwater and potable water, it is of usual reference (Flury, 1996). Triazines and triazinones are herbicides weakly basic which are protonated in acid soil, and in this way adsorbed by negative charges of colloids in the soil, decreasing as a consequence of its concentration in the soil solution. In this way, its persistence is positively correlated with the soil pH (Best et al., 1975; Weber et al., 1993). Microbian degradation also plays an important role in the persistence of these herbicides in the soil due to the fact that they are used as a source of energy and of nitrogen, decreasing in this way their availability in the soil solution (Bollag \& Liu, 1990). The persistence of these herbicides in the majority of types of soil also varies with climatic conditions. In that sense, the persistence increases with low temperature and/ or humidity (Harris \& Sheets, 1965; Harris et al., 1969).

Smith \& Walker (1989) reported that persistence of atrazine at $1.0 \mathrm{~kg} \mathrm{ha} \mathrm{h}^{-1}$ of a.i. in a clay textured soil with a $4,2 \%$ of OM varied from 206 days at $5^{\circ} \mathrm{C}$ up to 44 days at $30^{\circ} \mathrm{C}$, with the same humidity content in the soil. Similar results were obtained in other types of soil under equal humidity and temperature conditions (Walker, 1978; Walker \& Zimdahl, 1981). In soil of tropical regions the persistence decreases, having reported 70 days for rate of $3,0 \mathrm{~kg} \mathrm{ha}^{-1}$ of i.a. (Akinyemiju, 1991). Delmonte et al. (1997) determined for Argentina that atrazine persistence at $2.0 \mathrm{~kg} \mathrm{ha}^{-1}$ of a.i. in Balcarce soil $(\mathrm{OM}=5.7 \%)$ and San Cayetano soil $(\mathrm{OM}=3.8 \%)$ was of 143 and 221 days respectively. On the contrary, the half life of metribuzin can be of 3 to 7 days when it is applied on the soil surface, but if it is incorporated into the soil, the persistence increases two or three times (Jensen et al., 1989). At recommended rate, its persistence in the soil varies between 80 and 90 days (Sharom \& Stephenson, 1976). In the case of simazine, the persistence in the soil at the recommended rate is approximately of a one-year period of time only after which it is advisable to sow sensitive crops (Sheets \& Shaw, 1963). However, the Weed Science Society of America (1994) reported that simazine has moderate residual with an average field half-life of 60 days, whilst on high $\mathrm{pH}$ soils simazine persists longer.

The objective of this work was to determine the persistence of atrazine, metribuzin and simazine in two soils of the Southeast of Buenos Aires Province in Argentine.

\section{MATERIAL AND METHODS}

Greenhouse studies were conducted during 1994 and 1995 at the Balcarce Experimental Station of the Instituto Nacional de Tecnología Agropecuaria (INTA), Buenos Aires Province, Argentina.

Soil samples were collected from $0-15 \mathrm{~cm}$ depth at two different locations in Buenos Aires Province (Balcarce and San Cayetano). All sample sites had no previous history of use of the herbicides under study. Each soil sample was previously homogenized, air dried, and passed through a $2-\mathrm{mm}$ sieve before use. The properties of the soils are given in Table 1.

Soil samples were distributed into pots, in aliquots of $400 \mathrm{~g}$ dry weight (DSW), each one constituting an experimental unit. Herbicides and formulations used were: a) atrazine, aqueous flowable formulation at $50 \%$ active ingredient (a.i.), commercially distributed as Trac $50 \mathrm{FL}$ (Atanor S.A., Argentina); b) metribuzin, aqueous flowable formulation at $48 \%$ a.i., commercially distributed as Sencorex 48 (Bayer Argentina S.A.); c) simazine, aqueous flowable formulation at $50 \%$ a.i., commercially distributed as Simazina 50FL (Atanor S.A. Argentina). All herbicides were applied to soils diluted in water using a hand sprayer to achieve desired concentrations (Table 2).

Each sample was thoroughly mixed to allow a homogeneous distribution. Non-sprayed samples were used as 
controls. The experiment was conducted in a complete randomized design with crossed and nested factors (John, 1971): soil, herbicide and rate nested in herbicide. Each treatment was replicated six times.

Soils were evaluated for herbicidal activity using an oat bioassay (Sheets et al., 1962; Marriage, 1975; Horowitz, 1976). After herbicides were added to the soils, 13 oat seeds (Avena sativa, cv. Millauquén) were seeded per pot by pressing the basipetal end of each one into the soil up to approximately three quarters of its size. After seedling establishment, plant number was thinned to ten per pot. The seed bed was moistened daily with distilled water to $80 \%$ of field capacity.

Once the untreated control plants completely developed the second leaf, approximately in 30 days according to the time of the year, the growth period was considered come to an end. Plants were counted and evenly cut above the soil surface, placing all the harvest at $65^{\circ} \mathrm{C}$ until constant weight. Only live plants were harvested. Once weighed, plants were milled and returned to their corresponding pots, with a fallow period of about 20 days. Next, oat was again seeded in the way previously described This process was repeated until there were neither exter- nal symptoms of phythotoxicity in the plants nor differences among treatments (four periods). The four periods evaluated corresponded to seedings at $0,60,118$ and 184 days after treatment (DAT) and samplings at 36, 92, 155 and 224 DAT.

Relative dry weight (RDW) per plant was calculated as a percentage of the untreated control. The analysis of variance of the RDW was done for each sampling $(\alpha=0.01)$. For the analysis of the three first samplings three factors were considered: soil (two levels), herbicide (three levels) and rate (three levels) nested in herbicide. For the fourth sampling, only soil of San Cayetano was analyzed. Means of rates for each combination of herbicide and soil in all cases were compared by the Least Significant Difference Test (LSD) $(\alpha=0.01)$. The concentrations of herbicides required in soils to reduce shoot dry weight of oat, 50 percent (GR50) were calculated for the first crop (36 days) and for the two soils, as described by Sheets et al. (1962). The number of DAT required to obtain a RDW per plant of $80 \%$ was arbitrarily adopted as a way to determine phytotoxical persistence of herbicides among soils and graphically calculated between RDW vs. log of days until each sampling (Delmonte et al., 1997).

TABLE 1. Physicochemical properties of Balcarce and San Cayetano soils.

\begin{tabular}{lccccccc}
\hline Soil & $\mathrm{OM}^{1}$ & $\mathrm{pH}$ & Clay & Silt & Sand & Texture & $\begin{array}{c}\mathrm{CEC}^{2} \\
(\%)\end{array}$ \\
& $(\%)$ & $(1: 2.5)$ & $(\%)$ & $(\%)$ & $(\%)$ & & $\left(\mathrm{meq} \mathrm{g}^{-1}\right)$ \\
\hline Balcarce & 5.5 & 5.8 & 27.2 & 35.9 & 36.8 & Clay loam & 22.58 \\
San Cayetano & 2.9 & 6.7 & 29.7 & 30.0 & 40.1 & Clay loam & 20.64 \\
\hline
\end{tabular}

1 OM: organic matter content (Schnitzer, 1982).

${ }^{2}$ CEC: cation exchange capacity (Rhoades, 1982).

TABLE 2. Herbicides and rates evaluated.

\begin{tabular}{|c|c|c|c|c|c|}
\hline \multicolumn{6}{|c|}{ Herbicide } \\
\hline \multicolumn{2}{|c|}{ Atrazine } & \multicolumn{2}{|c|}{ Metribuzin } & \multicolumn{2}{|c|}{ Simazine } \\
\hline $\mathrm{kg} \mathrm{ha}^{-1}$ of a.i. & $\mu \mathrm{g} \mathrm{g}^{-1}$ of a.i. & $\mathrm{kg} \mathrm{ha}^{-1}$ of a.i. & $\mu \mathrm{g} \mathrm{g}^{-1}$ of a.i. & $\mathrm{kg} \mathrm{ha}^{-1}$ of a.i. & $\mu \mathrm{g} \mathrm{g}^{-1}$ of a.i. \\
\hline 0 & 0.00 & 0.00 & 0.00 & 0.00 & 0.00 \\
\hline 1 & 0.58 & 0.24 & 0.14 & 1.25 & 0.72 \\
\hline $2^{1}$ & 1.16 & $0.48^{1}$ & 0.28 & $2.50^{1}$ & 1.45 \\
\hline 4 & 2.32 & 0.96 & 0.56 & 5.00 & 2.90 \\
\hline
\end{tabular}

\footnotetext{
${ }^{1}$ Recommended rate
} 


\section{RESULTS AND DISCUSSION}

For each of the three first analysed dates, the differences between RDW due to the interaction soil $\mathrm{x}$ rate (herbicide) were highly significant $(p<0.01)$, as well as for the fourth sampling in San Cayetano soil. The activity of atrazine, metribuzin and simazine decreased throughout successive samplings, although it varied according to the type of soil and the applicated rate. In the case of atrazine in Balcarce soil, the three rates were significantly different in their activity at 36 DAT, while at 92 DAT only the rate of $2.32 \mu \mathrm{g} \mathrm{g}$-1 differed from the rest, and decreased its RDW in $64 \%$. At 155 DAT no significant differences were presented between the applied rates (Table 3 ). For metribuzin, the three rates were significantly different up to 36 DAT in both soils, while at 92 DAT only the rate of $0.56 \mu \mathrm{g} \mathrm{g}^{-1}$ produced significant decreases in RDW. At 155 DAT no significant differences between the three rates applicated were achieved (Table 4). For the simazine case in the Balcarce soil, the three rates applied differed significantly among themselves at 36 DAT, while at 92 DAT only the high rate differed. At 155 DAT no differences were presented (Table 5) and values very close to the maximum weight of reference were reached $(100 \%)$. For the San Cayetano soil, the rates of 1.45 and $2.9 \mu \mathrm{g} \mathrm{g-1}$ were the most phytotoxic, and they didn't differ significantly among themselves up to 155 DAT.

The persistence of atrazine in the Balcarce soil $(\mathrm{RDW}<80 \%)$ for the rates of $0.58,1.16$ and $2.32 \mu \mathrm{g} \mathrm{g}^{-1}$ was of 43,78 and 138 DAT, respectively. In the San Cayetano soil, the activity periods of the

TABLE 3. Relative dry weight (RDW) in different sampling periods from soils treated with atrazine'.

\begin{tabular}{lccccc}
\hline \multirow{2}{*}{ Soil } & Rate & \multicolumn{4}{c}{ RDW $(\%)$} \\
\cline { 3 - 6 } & $\left(\mu \mathrm{g} \mathrm{g}^{-1}\right.$ of a.i. $)$ & $36 \mathrm{DAT}^{2}$ & $92 \mathrm{DAT}$ & $155 \mathrm{DAT}$ & 224 DAT \\
\hline Balcarce & 0.58 & $76.9 \mathrm{a}$ & $104.3 \mathrm{a}$ & $100.4 \mathrm{a}$ & - \\
& 1.16 & $22.8 \mathrm{~b}$ & $96.9 \mathrm{a}$ & $94.9 \mathrm{a}$ & - \\
& 2.32 & $15.8 \mathrm{c}$ & $36.0 \mathrm{~b}$ & $95.8 \mathrm{a}$ & - \\
San Cayetano & 0.58 & $26.3 \mathrm{a}$ & $66.1 \mathrm{a}$ & $102.7 \mathrm{~b}$ & $101.1 \mathrm{c}$ \\
& 1.16 & $16.4 \mathrm{~b}$ & $28.7 \mathrm{~b}$ & $97.5 \mathrm{~b}$ & $128.9 \mathrm{a}$ \\
& 2.34 & $14.7 \mathrm{~b}$ & $31.7 \mathrm{~b}$ & $121.8 \mathrm{a}$ & $115.7 \mathrm{~b}$ \\
\hline
\end{tabular}

${ }^{1}$ For each soil, means within each column, followed by the same letter, do not differ significantly at the $5 \%$ level (Multiple Range Duncan Test). ${ }^{2}$ Days after treatment.

TABLE 4. Relative dry weight (RDW) in different sampling periods from soils treated with metribuzin'.

\begin{tabular}{lccccc}
\hline \multirow{2}{*}{ Soil } & Rate & \multicolumn{3}{c}{ RDW $(\%)$} \\
\cline { 2 - 5 } & $\left(\mu \mathrm{g} \mathrm{g}^{-1}\right.$ of a.i. $)$ & $36 \mathrm{DAT}^{2}$ & $92 \mathrm{DAT}$ & $155 \mathrm{DAT}$ & 224 DAT \\
\hline Balcarce & 0.14 & $96.6 \mathrm{a}$ & $106.2 \mathrm{a}$ & $101.3 \mathrm{a}$ & - \\
& 0.28 & $45.0 \mathrm{~b}$ & $114.2 \mathrm{a}$ & $100.8 \mathrm{a}$ & - \\
& 0.56 & $15.7 \mathrm{c}$ & $67.4 \mathrm{~b}$ & $110.7 \mathrm{a}$ & - \\
San Cayetano & 0.14 & $63.5 \mathrm{a}$ & $90.7 \mathrm{~b}$ & $112.3 \mathrm{a}$ & $101.1 \mathrm{ab}$ \\
& 0.28 & $23.3 \mathrm{~b}$ & $114.8 \mathrm{a}$ & $120.2 \mathrm{a}$ & $91.3 \mathrm{~b}$ \\
& 0.56 & $16.6 \mathrm{c}$ & $52.7 \mathrm{c}$ & $119.6 \mathrm{a}$ & $111.6 \mathrm{a}$ \\
\hline
\end{tabular}

${ }^{1}$ For each soil, means within each column, followed by the same letter, do not differ significantly at the $5 \%$ level (Multiple Range Duncan Test).

${ }^{2}$ Days after treatment. 
TABLE 5. Relative dry weight (RDW) in different sampling periods from soils treated with simazine'.

\begin{tabular}{lccccc}
\hline \multirow{2}{*}{ Soil } & Rate & \multicolumn{4}{c}{ RDW $(\%)$} \\
\cline { 2 - 5 } & $\left(\mu \mathrm{g} \mathrm{g}^{-1}\right.$ of a.i. $)$ & $36 \mathrm{DAT}^{2}$ & $92 \mathrm{DAT}$ & $155 \mathrm{DAT}$ & 224 DAT \\
\hline Balcarce & 0.72 & $87.2 \mathrm{a}$ & $106.2 \mathrm{a}$ & $96.4 \mathrm{a}$ & - \\
& 1.45 & $30.2 \mathrm{~b}$ & $92.6 \mathrm{~b}$ & $99.8 \mathrm{a}$ & - \\
& 2.90 & $20.6 \mathrm{c}$ & $46.1 \mathrm{c}$ & $95.0 \mathrm{a}$ & - \\
San Cayetano & 0.72 & $24.3 \mathrm{a}$ & $64.2 \mathrm{a}$ & $123.9 \mathrm{a}$ & $141.9 \mathrm{a}$ \\
& 1.45 & $19.8 \mathrm{ab}$ & $42.3 \mathrm{~b}$ & $79.8 \mathrm{~b}$ & $136.8 \mathrm{a}$ \\
& 2.90 & $17.8 \mathrm{~b}$ & $35.7 \mathrm{~b}$ & $73.4 \mathrm{~b}$ & $115.0 \mathrm{~b}$ \\
\hline
\end{tabular}

${ }^{1}$ For each soil, means within each column, followed by the same letter, do not differ significantly at the $5 \%$ level (Multiple Range Duncan Test). 2 Days after treatment.

herbicide were longer (Table 6), reaching approximately 123,130 and 145 DAT for the rates of 0.58 , 1.16 and $2.32 \mu \mathrm{g} \mathrm{g}-1$, respectively. At 155 and 224 DAT, the oat plants evened up or exceeded the test value without herbicide $(100 \%)$. The persistence (RDW $<80 \%$ ) of metribuzin in the Balcarce soil was of 29, 63 and 110 DAT, approximately, while in the San Cayetano soil was about 75,77 and 121 DAT for the rates of $0.14,0.28$ and $0.56 \mu \mathrm{g} \mathrm{g}^{-1}$, respectively (Table 6). The persistence of simazine in the Balcarce soil (RDW $<80 \%$ ) was of 32,81 and $137 \mathrm{DAT}$ for the rates of $0.72,1.45$ and $2.9 \mu \mathrm{g} \mathrm{g}^{-1}$, respectively. In the San Cayetano soil, the persistence was about 110 , 156 and 177 DAT for the rates of $0.72,1.45$ and $2.9 \mu \mathrm{g}$ $\mathrm{g}^{-1}$, respectively (Table 6).

The rates of atrazine, metribuzin and simazine necessary to reduce oat plants growing in a $50 \%$ for the first sampling (36 DAT) indicated that, for the three herbicides applied, the values of $\mathrm{GR}_{50}$ were lower in the San Cayetano soil than in Balcarce (Table 7). At the same time, herbicides ordered by degree of phytotoxicity considered for both types of soil were as follows: metribuzin > atrazine $>$ simazine. These values suggest that metribuzin required lower rate to cause a decrease in growing of $50 \%$ than the other herbicides.

Low rates of the three herbicides in general were less phytotoxic in the Balcarce soil than in the San Cayetano soil. In both soils a stronger atrazine activity $\left(0.58 \mu \mathrm{g} \mathrm{g}^{-1}\right)$ was observed, compared to simazine $\left(0.72 \mu \mathrm{g} \mathrm{g}^{-1}\right)$ and metribuzin $\left(0.14 \mu \mathrm{g} \mathrm{g}^{-1}\right)$. For the case of the recommended rate, atrazine
TABLE 6. Persistence (RDW $<80 \%$ ) of atrazine, metribuzin and simazine according to rate and soil types, evaluated by days after treatment (DAT).

\begin{tabular}{lccc}
\hline Herbicide & $\begin{array}{c}\text { Rate } \\
\left.\text { ( } \mathrm{g} \mathrm{g}^{-1} \text { of a.i. }\right)\end{array}$ & $\begin{array}{c}\text { Balcarce } \\
(\mathrm{DAT})\end{array}$ & $\begin{array}{c}\text { San Cayetano } \\
(\mathrm{DAT})\end{array}$ \\
\cline { 3 - 4 } Atrazine & 0.58 & 43 & 123 \\
& 1.16 & 78 & 130 \\
& 2.32 & 138 & 145 \\
Metribuzin & 0.14 & 29 & 75 \\
& 0.28 & 63 & 77 \\
Simazine & 0.56 & 110 & 121 \\
& 0.72 & 32 & 110 \\
& 1.45 & 81 & 156 \\
& 2.90 & 137 & 177 \\
\hline
\end{tabular}

TABLE 7. Rate of atrazine, metribuzin and simazine necessary to produce a growth reduction of $50 \%\left(\mathbf{G R}_{\mathbf{5 0}}\right)$.

\begin{tabular}{lccc}
\hline Soil & Atrazine & Metribuzin & Simazine \\
\hline & - & & \\
& & & \\
Balcarce & 0.84 & 0.47 & 2.22 \\
San Cayetano & $<0.58$ & 0.32 & $<1.45$ \\
\hline
\end{tabular}


$\left(1.16 \mu \mathrm{g} \mathrm{g}^{-1}\right)$ and simazine $\left(1.45 \mu \mathrm{g} \mathrm{g}^{-1}\right)$ were more phytotoxic than metribuzin $(0.28 \mu \mathrm{g} \mathrm{g}-1)$ in both types of soil studied, although the differences in San Cayetano were more denoted. For these rates, metribuzin did not produce phytotoxicity from 80 to 85 DAT for Balcarce and San Cayetano respectively. In the case of atrazine and simazine, this situation lasted for more days in the San Cayetano soil. With high rate, atrazine $\left(2.32 \mu \mathrm{g} \mathrm{g}^{-1}\right)$ and simazine $(2.90 \mu \mathrm{g}$ $\left.\mathrm{g}^{-1}\right)$, except in the first sampling, presented more activity than metribuzin $\left(0.56 \mu \mathrm{g} \mathrm{g}^{-1}\right)$ in Balcarce. Also, in San Cayetano simazine presented more activity than atrazine and metribuzin after 90-95 DAT, approximately.

The persistence of herbicides in the soil is related to OM content, $\mathrm{pH}$, cation exchange capacity (CEC) and texture (Green, 1974; Weed \& Weber, 1974). Works done with atrazine, metribuzin and simazine, determined that $\mathrm{OM}$ was the main factor which explained their persistence, being the CEC and the clay content of less importance (Sheets et al., 1962; Sheets $\&$ Shaw, 1963; Horowitz, 1969). Therefore, the adsorption degree of these herbicides is positively correlated with OM content and negatively with their persistence. According to the characteristics of the soils studied (Table 1), it is pointed out that the main difference between the soil in Balcarce and San Cayetano was due to OM content. Therefore, this variable mainly determined the difference in persistence of herbicides in soils. In that sense, the oat RDW was the most affected by the three herbicides and the evaluated rates for the soil in San Cayetano than for the one in Balcarce. Weber et al. (1993) referred that bioactivity (weed control) of many weakly basic herbicides is inversely related to the organic matter content of soils.

Independently from the soil, herbicide persistence also keeps a close relationship with the initial rate applied (Horowitz, 1969). In this trial it was determined that when increasing the rate, persistence of herbicides also increased, being this longer in San Cayetano soil for the three herbicides, results coincident with what wehe reported by Delmonte et al. (1997).
As it has already been expressed, $\mathrm{pH}$ is another important factor that affects the persistence of atrazine, metribuzin and simazine in soil (Weber et al., 1993; Weed Science Society of America, 1994). Triazines and triazinones, weakly basic herbicides, are protonated in acid soil, being adsorbed by negatively charged colloids, giving as a result a lower concentration of herbicide in the available solution for absorption by plants (Weber et al., 1968). However, metribuzin has a low pK (1-1.1), what indicates that below pH 3 it starts suffering protonation and in this way it can be adsorbed to the colloids in the soil, while above $\mathrm{pH} 3$ it is weakly adsorbed (Weber, 1980; Albro \& Parker, 1984). Atrazine and simazine have a $\mathrm{pK}$ value of 1.68 and 1.5 , respectively; therefore, metribuzin reached a lower persistence in both types of soil than simazine and atrazine. On the other hand, the lower $\mathrm{pK}$ value of simazine, as well as its lower solubility (4 ppm) respect to atrazine (30 ppm), explained its stronger persistence in both types of soil for every applicated rate. Best et al. (1975) determined that the $\mathrm{pH}$ increase from 5.5 to 7.5 , through liming technique, increased phytotoxicity and atrazine persistence, not allowing protonation and, as a consequence, its retention in the colloidal system. In the same manner, Slack et al. (1978) determined that persistence of simazine in the soil increased with increasing soil $\mathrm{pH}$. The high persistence of herbicides in the San Cayetano soil respect to the one of Balcarce was mainly due to the lower OM content (2.9\%), but also to a higher $\mathrm{pH}$ (6.7). In this way, the $\mathrm{pH}$ should act in this experiment as a second factor of the soil in order of importance when determining the persistence of herbicides.

Considering the recommended rate of herbicides, a minimum of 78 and 130 DAT for atrazine, 63 and 77 DAT for metribuzin and 81 and 156 DAT for simazine were necessary for Balcarce and San Cayetano soils, respectively, to achieve a RDW of $80 \%$ (Table 7). Therefore, metribuzin was the least persistent in both types of soil considered and simazine was the most persistent, finding in atrazine an intermediate behaviour. These results suggest that for atrazine and simazine longer periods of time than metribuzin should be taken into account in order to 
avoid damages to sensitive crops. Likewise, in order to minimize the risk of environmental pollution, the rational use of atrazine, metribuzin and simazine implies the application at recommended rates for each region and taking into account the characteristics of the soils and herbicides.

\section{CONCLUSIONS}

1. Persistence of atrazine, metribuzin and simazine increases with low organic matter content and high $\mathrm{pH}$ of the soils.

2. Persistence of atrazine, metribuzin and simazine varies with the rate applied.

3. For Balcarce soil, persistence of atrazine, metribuzin and simazine at recommended rates are 78, 63 and 81 days after application, respectively.

4. For San Cayetano, soil persistence of atrazine, metribuzin and simazine at recommended rates are 130, 77 and 156 days after application, respectively.

5. For the soils studied, persistence of the herbicides at recommended rates follows the order simazine $>$ atrazine $>$ metribuzin.

\section{REFERENCES}

AKINYEMIJU, O.A. Persistence of atrazine in a humid tropical soil in the early and late cropping seasons Turrialba, v.41, n.2, p.129-134, 1991.

ALBRO, P.; PARKER, C. Determination of the $\mathrm{pK}_{\mathrm{a}}$ values of metribuzin and three of its metabolites: a comparison of spectrophotometric and potentiometric methods. Journal of Agricultural and Food Chemistry, v.32, p.212-217, 1984

BEST, J.A.; WEBER, J.B.; MONACO, T.J. Influence of soil $\mathrm{pH}$ on s-triazine availability to plants. Weed Science, v.23, p.378-382, 1975.

BOLLAG, J.M.; LIU, S.Y. Biological transformation processes of pesticides. In: CHENG, H.H. (Ed.). Pesticide in the soil environment: processes, impacts, and modeling. Madison: Soil Science Society of America, 1990. p.169-211.

DELMONTE, A.A.; BEDMAR, F.; MANTECON, J.D.; ECHEVERRIA, H.; BARASSI, C.A. Residual phytotoxicity and chemical persistence of atrazine in soils of the southeast of Buenos Aires Province,
Argentina. Journal of Environmental Biology, v. 18, n.3, p.201-207, 1997.

FLURY, M. Experimental evidence of transport of pesticides through field soils-a review. Journal of Environmental Quality, v.25, p.25-45, 1996.

GREEN, R.E. Pesticide-clay-water interactions. In: GUENZI, W.D. (Ed.). Pesticides in soil \& water: Madison: Soil Science Society of America, 1974. p.3-37.

HARRIS, C.; SHEETS, T. Influence of soil properties on adsorption and phytotoxicity of CIPC, diuron and simazine. Weeds, v.13, p.215-219, 1965.

HARRIS, C.I.; WOOLSON, E.A.; HUMMER, B.E. Dissipation of herbicides at three soil depths. Weed Science, v.17, p.27-31, 1969

HOROWITZ, M. Application of bioassay techniques to herbicide investigations. Weed Research, v.16, p.209-215, 1976.

HOROWITZ, M. Evaluation of herbicide persistence in soil. Weed Research, v.9, p.314-321, 1969

JENSEN, K.; IVANY, J.; KIMBALL, E. Effect of canopy and incorporation on metribuzin persistence in soils. Canadian Journal of Soil Science, v.69, p. 711-714, 1989

JOHN, P.W.M. Statistical design and analysis of experiments. New York: MacMillan, 1971.365p.

MARRIAGE, P.B. Detection of triazine and urea herbicide residues by various characteristics of oat seedlings in bioassays. Weed Research, v.15, p.291-298, 1975.

RHOADES, J.D. Cation exchange capacity. In: PAGE,A.L; MILLER, R.H.; KEENEY, D.R. (Eds.). Methods of soil analysis. Part 2-Chemical and microbiological properties. 2.ed. Madison: American Society of Agronomy, Soil Science Society of America, 1982. p.149-157.

SATTIN, M.; BERTI, A.; ZANIN, G. Agronomic aspects of herbicide use. In: VIGHI, M.; FUNARI, E. (Eds.). Pesticide risk in groundwater. Boca Raton: CRC, 1995. p.45-70.

SCHNITZER, M. Organic matter characterization. In: PAGE, A.L.; MILLER, R.H.; KEENEY, D.R. (Eds.). Methods of soil analysis. Part 2- Chemical and microbiological properties. 2.ed. Madison: American Society of Agronomy, Soil Science Society of America, 1982. p.581-594.

Pesq. agropec. bras., Brasília, v.34, n.11, p.2037-2044, nov. 1999 
SHAROM, M.S.; STEPHENSON, G.C. Behaviour and fate of metribuzin in eight Ontario soils. Weed Science, v.24, p.153-160, 1976

SHEETS, T.J.; CRAFTS, A.S.; DREVER, H.R. Soil effects on herbicides. Influence of soil properties on the phytotoxicities of the s-triazine herbicides. Journal of Agricultural and Food Chemistry, v. 10, p.458$462,1962$.

SHEETS, T.J.; SHAW, W.C. Herbicidal properties and persistence in soil of s-triazines. Weed Science, v.11, p.15-21, 1963.

SLACK, C.H.; BLEVINS, R.L.; RIECK, C.E. Effect of soil $\mathrm{pH}$ and tillage on persistence of simazine. Weed Science, v.26, p.145-148, 1978.

SMITH,A.; WALKER, A. Prediction of the persistence of the triazine herbicides atrazine, cyanazine, and metribuzin in Regina heavy clay. Canadian Journal of Soil Science, v.69, p. 587-595, 1989

TALBERT, R.E.; FLETCHALL, O.H. The adsorption of some s-triazines in soil. Weeds, v.13, p.46-52, 1965.

WALKER, A. Simulation of the persistence of eight soilapplied herbicides. Weed Research, v.18, p.305313,1978
WALKER, A.; ZIMDAHL, R.L. Simulation of the persistence of atrazine linuron and metolachlor in soil at different sites in the U.S.A. Weed Research, v.21, p.255-265, 1981.

WEBER, J.B. Ionization of buthidazole, VEL 3510 , tebuthiuron, fluridone, metribuzin and prometryn. Weed Science, v.28, p.467-474, 1980.

WEBER, J.B.; BEST, J.A.; GONESE, J.U. Bioavailability and bioactivity of sorbed organic chemicals. In: LINN, D.M.; CARSKI, T.H.; BRUSSEAU, M.L.; CHANG, F.H. (Eds.). Sorption and degradation of pesticides and organic chemicals in soil. Madison: Soil Science Society of America, 1993. p.153-196.

WEBER, J.B.; PERRY, P.W.; IBARAKI, K. Effect of $\mathrm{pH}$ on the phytotoxicity of prometryne applied to synthetic soil media. Weed Science, v.16, p.134-136, 1968.

WEED, S.B.; WEBER, J.B. Pesticide-organic matter interactions. In: GUENZI, W.D. (Ed.). Pesticides in soil \& water. Madison: Soil Science Society of America, 1974. p.39-66.

WEED SCIENCE SOCIETY OF AMERICA. Herbicide handbook of the WSSA. 7.ed. Champaign: Weed Science Society of America, 1994. 352p. 